\title{
THE EIGHTH GRADE STUDENTS' SATISFACTIONS ON THE ENGLISH TEACHER PROFESSIONALISM IN TEACHING ENGLISH AS FOREIGN LANGUAGE AT SMP NEGERI 8 SINGARAJA IN ACADEMIC YEAR 2018/2019
}

\author{
L.Sari ${ }^{1}$, Sudirman ${ }^{2}$, L.D.S Adnyani ${ }^{3}$ \\ Program Studi Pendidikan Bahasa Inggris \\ Jurusan Bahasa Asing \\ Universitas Pendidikan Ganesha \\ Singaraja, Indonesia \\ E-mail: liana.sari@undiksha.ac.id, dirman p@yahoo.co.id, luh diah@yahoo.com
}

\begin{abstract}
ABSTRAK
Penelitian ini bertujuan untuk mengetahui kepuasan siswa kelas delapan terhadap profesionalitas guru bahasa Inggris di SMP Negeri 8 Singaraja pada tahun ajaran 2018/2019. Objek dari penelitian ini adalah profesionalitas guru bahasa inggris. Subjek dari penelitian ini adalah 151 siswa kelas VIII di SMP Negeri 8 Singaraja. Data dari penelitian ini diperoleh menggunakan kuisioner dan lembar pertanyaan wawancara kepada siswa kelas delapan (VIII). Penelitian ini menggunakan pendekatan metode campuran karena penulis menggabungkan dua metode kuantitatif dan kualitatif dalam menganalisis data. Penelitian ini menyimpulkan bahwa berturut-turut nilai rata-rata dari variabel keandalan, ketanggapan, empati, jaminan, dan bukti fisik yakni mendapatkan nilai rata-rata 3.9, 3.89, $4.1,4.1$, dan 4.1 yang berarti semua variable berada pada tingkat puas. Akhirnya, dari analisis data, dapat disimpulkan bahwa siswa memiliki kepuasan yang positif terhadap profesionalitas guru bahasa inggris dalam belajar bahasa inggris.
\end{abstract}

Kata-kata kunci: Kepuasan siswa, Profesionalitas guru.

\begin{abstract}
This research aimed to know the eighth grade students' satisfaction on the English teacher professionalism in teaching English as Foreign Language at SMP Negeri 8 Singaraja in academic year 2018/2019. The object of this research was English teacher professionalism. The subject of this research was 151 eighth grade students' satisfaction at SMP Negeri 8 Singaraja. The data of this research were obtained by using questionnaire and interview question sheet to the students. This research was used mixed-method approach because the writer combines both quantitative and qualitative method in analyzing the data. This result indicate that average score from reliability, responsiveness, empathy, guarantee and physical evidence which get an average score of 3.9, 3.89, 4.1, 4.1, and 4.1 that means all of variables are in the satisfying level. Finally, it can be concluded that students are showing positive respond against english teacher professionalism in English learning
\end{abstract}

Keywords: Students' Satisfaction, Teacher Professionalism. 


\section{INTRODUCTION}

In educational field, teachers' quality is very important. It is because one of the main parts on education is teacher. Teacher takes crucial role in the teaching and learning process. According to Kumbakonam (2017:03), there are five important roles of teachers that should be mastered to be a good teacher, namely: teacher as a learner, teacher as a facilitator, teacher as an assessor, teacher as a manager, and teacher as an evaluator. All of those roles should be mastered to keep the quality of the teacher. Moreover, the quality of teacher can give positive impact towards the students' English proficiency. As Ulug, Ozden, \& Eryilmaz (2011:742) argued in their investigation, quality of teacher from their attitudes point of view gives positive impact towards the students' personality and also the students' attitudes during teaching and learning process. They also discussed that the most important findings on their investigation evidenced that teachers' positive attitudes have positively influenced students' personality as well as their life performances. Participants on this study generally described teachers' positive attitude as compassionate, understanding, helpful, seeing the student as an individual, being friendly and interested, communicating, as well as being genuine and tolerant, supporting, motivating, and encouraging participation in social events. Meanwhile, teachers' negative attitude on their study is listed as discrediting, vengeful, too disciplined, uninterested, favoritism, being angry, not caring, being intolerant, not understanding, and being inconsistent.

In addition, quality of the teachers can also be seen from their professionalism. Some studies proved that teachers' professionalism can give positive improvement to the students' academic achievements. Khan (2017:48) discussed this on his library research after the review of different research articles concerned with teaching professionalism and the students learning process. It is confirmed that professional attitudes of teachers have great impact on the academics of the students. Such emerging concept is supported by the studies whose findings indicated that professional attitudes of teachers have great impact on the students' academics (Eggen \& Kauchak, 2001; Bain \& Ken, 2004 \& Chelo, 2010:51). These studies have shown that positive professional attitudes have significant role in the academic success of the students.

Teachers' professionalisms in teaching and learning process are the crucial factor that should be concerned by all of the teachers. It is because the successful of teaching and learning process is also determined by how the students perceive their teachers' professionalism to achieve the goal of the lesson. The importance of teachers' professionalism also has a close relation to students' satisfaction in teaching and learning process. A study in Indonesia conducted by Suarman (2015:626) revealed that the relationship between lecturers and students determines the lecturers' teaching quality and students' satisfaction. The findings confirm the role theory of relationship between lecturers and students, as well as the impact of teaching quality in enhancing students' satisfaction as found in various studies conducted abroad, particularly on the constructs being studied. Based on his study, it raises an indication that students' satisfaction also takes a crucial part besides the relationship between teachers and students. It also determines the goals which are achieved during the learning process.

According to Guolla (1999:19), satisfaction is an evaluation which takes place at the end of the process of consumer psychology after the use of a product or service. Students' satisfaction on their learning program is considered as a cumulative satisfaction of the entire program of their study. Students are clients whose interests and satisfaction need to be prioritized as a dependent variable. Guolla (1999:19) also states that students are clients, and their satisfaction on certain educational products or services is resulted through interaction between lecturers and students during their teaching and learning process. Every teaching and learning activity has its own setbacks or constraints. Hence, students who can resolve obstacles and constraints have higher satisfaction than those who cannot and relatively have lower satisfaction. Successful students are those who know their own ability and capable in developing themselves through learning. 
Moreover, in Albanian context, it was found that a study in higher education related to quality of several universities influenced the students' satisfaction (Uka, 2014:06). On his investigation, he proved that there were gender differences in which male students scored higher than female students $(p<.05)$ on most of the students' services provided by the university. Single factor ANOVA showed that students from different university groups differed significantly $(F(4,195)=6.15, p<.05)$ on students' services. It means that score differences among the students in different universities were caused by different quality services in every university which makes different level of students' satisfaction.

On educational field, it cannot be avoided that students' satisfaction becomes a phenomenon to be concerned by the teachers and other institution which has close relation to schools' environment. Many researchers have conducted study related to students' satisfactions and their roles on the educational field as it is discussed above. Deeply, Race (2010:04) argued that "To increase students' satisfaction we need to take time to talk with students about their experience, not just in their final year, but all along their pathway through university, and we need to make time to listen to their views. We need to find out from students all the other things that are important in their higher education experience include their feelings". From this statement, it can be inferred that students' satisfactions are important to be concerned. Although his statement in higher education context but again, it is an indication that satisfaction has a crucial part on this point of view.

The same case with a different result on Indonesian context proved that teachers on a Senior High School at Kartasura gave negative result for the students' satisfaction towards their certified teachers (Islamiyah, 2017:05). She proved that the level of students' satisfaction on learning with certified teachers did not satisfy the students compared to the performance of non-certified teachers during the learning process. They were not satisfied because of some indicators of students' satisfaction levels that had not been met. Those indicators were empathy related to mastery of the characteristics of learners from the aspect of physic, moral, spirit, social, culture, emotion, intellectuality, and tangible indicators in the use of information technology and communication for learning purposes. Based on this evidence, it can be concluded that it cannot be guaranteed that the certified teachers can give quality teaching for the students.

Formally, the Republic of Indonesia Law No. 20 of 2003 concern with the national education system, Law of the Republic of Indonesia No. 14 of 2005 concern with teachers and lecturers and Government Regulation No. 19 of 2005 concern with National Education Standards states that teachers are professionals. Professional teachers must have a minimum academic qualification of undergraduate (S-1) or diploma 4 (D-4), master competence (pedagogic, professional, social and personality), have a certificate of educator, are physically and mentally healthy, and have the ability to realize educational goals national. Recognition of the position of the teacher as a professional staff is evidenced by the educator certificate obtained by certification (Muslich, 2012:5). The certification program carried out by the government in fact still requires a lot of improvement from the government, related educational institutions, and the community so that the certification program is carried out in an optimal manner. In various cases, teachers who have been certified do not experience any development in providing learning services to students because merely the certification program is only to improve the welfare and quality of teaching that they have as well as when they have not participated in the certification program.

Moreover, the data from Kemendikbud in 2016 related to teachers' professionalism in Indonesia showed that the average score of UKG (Uji Kompetensi Guru) was not too good, in which the average score was only $64.92 \%$. UKG is the exam for the Indonesian teachers to make sure that the teachers are professional in doing their job as a teacher. The low average score in 2016 also means that most of the teachers in Indonesia were not good enough on the professionalism context, that's why PKB (Pengembangan Keprofesian Berkelanjutan) is important to be implemented to the teachers to reach the high score (Kemendikbud, 2017). 
Because student satisfaction includes things related to the learning process carried out by the teacher, it will be conducted research on the factors that influence the satisfaction of the eighth grade students in SMP Negeri 8 Singaraja. These factors consist of reliability, responsiveness, empathy, assurance, and tangibility (Sopiatin, 2010:40). Students can see and assess how the learning process carried out by the teachers at SMP Negeri 8 Singaraja where students are as consumers and can provide perceptions of teachers who provide educational services. After pre-observation in all junior high schools in Singaraja City. Researchers found that one school that had a phenomenon was different among other junior high schools. The school was SMP Negeri 8 Singaraja which was only established two years ago. SMP Negeri 8 Singaraja only had two levels, namely seventh grade and eighth grade with fifteen teachers with two English teachers. Here the researcher found a phenomenon in which English teachers at SMP Negeri 8 Singaraja had different backgrounds. The first English teacher has taught for two years at SMP Negeri 8 Singaraja have a background in English Language Education while the second English teacher who has just taught for one year does not have an educational background or English Literature. Based on the description above, researcher was interested in took the research about the level of satisfaction with learning by teachers in English Literature background at SMP Negeri 8 Singaraja in 2018/2019.

Some studies has been conducted in students' satisfaction on teachers' professionalism. Yani (2015:15) has conducted an investigation on EFL context related to teachers' professionalism. Another study was conducted by Carter (2014:72) about student satisfaction in theory and practice. Students' satisfaction has rarely been qualitatively studied at university level.Other study was conducted by Barnes (2017:92) about an analysis of student perceptions of the quality and course satisfaction of online courses.Further, a study about teaching professionalism and student academic achievements was conducted by Khan (2017:48) who reviewed that a study was an attempt to explore the satisfaction of various researchers about teaching professionalism and its effects on students' academics.

\section{METHOD}

This research is categorized as mixed-method approach because the writer combines both quantitative and qualitative method in analysing the data. For the design of the research, the writer uses Sequential ExplanatoryDesign, Creswell (2009). Quantitative data were gained through questionnaire and qualitative data were gained through interview also field note. The data obtained from questionnaire were calculated by using formulas and then the calculated data were described into words. Quantitative and qualitative data completed each other (Klette, 2012). Quantitative data were supported by qualitative data. Quantitative data were collected first and then qualitative data were collected next.The procedure of this research were identifying the populations and samples of the study, developing research instrument, collecting quantitative data through questionnaire, analysing quantitative data, collecting qualitative data through interview guide, analysing qualitative data, interpreting of entire analysis, and the last was writing report.

This study was conducted at SMP Negeri 8 Singaraja, Buleleng because this school was a new public junior high school in Singaraja. The school was established two years ago. SMP Negeri 8 Singaraja only had two levels, namely seventh grade and eighth grade. There are fifteen teachers with two English teachers. Here, the researcher found a phenomenon in which English teachers at SMP Negeri 8 Singaraja had different backgrounds. The first English teacher has taught for two years at SMP Negeri 8 Singaraja have a background in English Language Education while the second English teacher who has just taught for one year does not have an educational background or English Literature. There are two grade 
only in SMP Negeri 8 Singaraja, namely seventh and eighth grade students and this school have not ninth grade, so the research choose eighth grade for the participants because the eighth students have been studying English subject more than 1 year. The researcher involved 151 students from eighth grade students. So, it means that there was an indication that the teachers did not pass the UKG to fulfil the professionalism requirement.

The population in this study were all of the eighth grade students who took English subject at SMP Negeri 8 Singaraja as many as 151 Students. In the sample, this study used census technique to determine the sample because all the eighth grade become the sample.

In this researcher there are three method to collect the data as followed: Observation (non-participant), Survey, and Interview. For the research instrument, the researcher used questionnaire in the form of Close-ended questionnaire because it was quantified and used interview form for interview.

The collected data from Questionnaire were analyzed quantitatively. The steps were collecting the data, tabulating data, data classification, and analyzing data by using frequency analysis SPSS 22. The data from interview were analyzed qualitatively with the theory of interactive data analysis, containing of three steps, namely data reduction, data display, and conclusion drawing/verifying (Miles, Huberman, \& Saldana, 2014:118).

The data about student satisfaction with the English teacher in the learning process will be described descriptively with a measurement scale that is the Likert ScalePresentation of the data used is if very satisfied given a value of 5 , satisfied answers given a value of 4 , satisfied enough to be given a value of 3 , dissatisfied given a value of 2 and for the answer is very dissatisfied given a value of number 1 .

\section{FINDING AND DISCUSSION}

The instrument used in this research is a questionnaire with a closed statement that is measured using a table of five degrees. Before a valid questionnaire is used as an instrument for data collection, then validity and reliability tests are carried out first by distributing 30 questionnaires to eighth grade students of SMP Negeri 8 Singaraja. There are 5 variables of student satisfaction towards English teachers who teach in the classroom, namely reliability, responsiveness, empathy, assurance and tangibility with 20 indicators of questions that will be tested for validity and reliability.

The reliability variable has 5 question indicators, namely: (X1) the teacher's ability to connect with students in the class, (X2) the teacher's ability to condition the class, (X3) the teacher's ability to communicate with students in the class, (X4) teacher's ability in using learning media to increase student attention, (X5) the ability of teachers to deliver learning material to students.

The responsiveness variable has 2 indicators of questions, namely: (X6) teachers are swift in responding to student complaints in the classroom, (X7) teachers are swift in providing information needed by students.

Empathy variables have 2 question indicators, namely: (X8) Teachers can attract my attention in the teaching and learning process, (X9) Teacher's concern for students who have difficulty learning in class

Assurance variables have 8 question indicators, namely: (10) teachers treat students fairly in the classroom, (X11) teachers master the subject matter well, (X12) the teacher is able to answer questions posed by students, (X13) teachers teach accordingly with an 
educational background, (X14) the teacher utilizes learning material to enhance students' self-potential, (X15) the teacher is able to provide comfort to students in the class, (X16) teachers present on time while teaching in class, $(\mathrm{X} 17)$ the teacher never skips during the learning process

Tangibility variables have 3 question indicators, namely: (X18) teachers are always in class during the teaching and learning process, (X19) teachers always dress neatly and politely while in a school environment, (X20) teachers use adequate learning media

Validity test is the testing of instruments or measuring instruments aimed at knowing the suitability between the measuring instrument and the items from the indicators measured, so that by testing this validity the researcher is able to interpret the data used. Each question in the questionnaire is considered valid if the r-count shows a greater result than the r-table, where $\mathrm{df}=\mathrm{N}-2, \mathrm{~N}$ for the validity and reliability test in this study is 30 so that $\mathrm{df}=30-2=28$. So df 28 in table $r$ statistic is 0.361 .

The reliability test for the variables in this study used the Cronbach's Alpha $(\alpha)$ method. If the results of the reliability test exceed Cronbach's Alpha $(\alpha)$, which is 0.600 , then the indicators used in the questionnaire are declared reliable or can be considered as a variable measurement tool (Hair et al, 1995).

From the results of the instrument feasibility test, it shows that all question items have $r$-count values exceeding the r-table value of 0.361 and have cronbach's $(\alpha)$ alpha values exceeding 0.600 so all variables of participation forms are valid and reliable, so there is no question items that must be eliminated.

After the questionnaires were spread on 151 respondents at SMP Negeri 8 Singaraja, the researcher find the result.

Figure 4.1

Satisfaction chart of eight grade students

toward the professionalism of English teachers

at SMP Negeri 8 Singaraja

$\mathrm{n}=151$

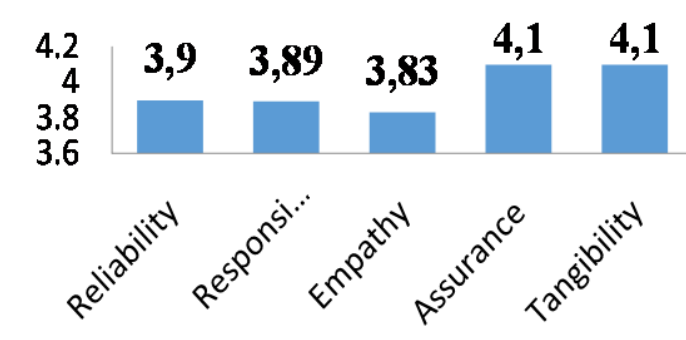

Level of students satisfaction

From the results of questionnaire data processing to eight grade students, it can be seen from Figure 4.1 the average value in the reliability variable gets an average value of 3.9 
which means satisfied, then the responsiveness variable gets an average value of 3.89 which means satisfied, the empathy variable got an average value of 3.83 which means satisfied, then the variable assurance obtained an average value of 4.1 which means satisfied, and the last is the tangibility variable which is getting an average value of 4.1 which meaning satisfied.

Based on the figure 4.1, on this part the researcher will interpret the data more detail into the specific aspects of each dimensions. Generally looking at the figure above the highest score comes from assurance and tangibility dimensions. It means that most of the eight grade students agreed or satisfied that their teacher is tangible and assurance. Based on the data above also it can be interpreted that the lowest score comes from the empathy dimension, it means that most of the students gave the low point into this part. Firstly, on this discussion the researcher will describe the data more detail from the reliability dimension. As we have discussed before that, reliability relates to the teacher's ability to provide quality teaching and learning services in accordance with what is promised, consistent, and the school develops a curriculum that is appropriate to the needs and expectations of students. Second, the data more detail from Responsive Dimension. As we have discussed before that responsive is willingness of school personnel to hear and resolve student complaints related to school problems concerning teaching and learning problems or personal problems. Third, we have discussed that Empathy is the teacher's attitude in providing service wholeheartedly. It is such as personal attention and understanding that each student has different abilities and needs. This attitude can be demonstrated by understanding the role of the teacher who is not only an educator, but also as counselor. Forth, Quality assurance dimensions related to the behavior of teaching staff or teachers in instilling a sense of trust and confidence in students. Assurance includes competence, knowledge, skills and politeness. The last part is a score based on the Tangibility dimension, as we know that tangible is a physical dimension. A service cannot be kissed and cannot be touched, so physical evidence becomes important as a measure of service. Tangible is the ability to provide physical facilities for schools and adequate school supplies. An interesting data also shown from the item number two in which it gets the highest score on tangibility dimension. Most of the students feel satisfy of their teacher when their teacher used a good uniform. On this phenomenon it can be said that most of the students like the teacher who are looking good and wearing a nice uniform during teaching and learning process because when the teacher teaches in the classroom she will be the center point of the students' attention so that's why appearance is important for teacher during the classroom activities.

It can be conclude that the professionalism of English teacher from English Literature background at SMP Negeri 8 Singaraja is satisfied. It can be seen from response of the students in the questionnaire which showed that the students are satisfied with the English teachers' performance and professionalism.

\section{CONCLUSION}

Based on the discussion and the result about the eighth grade students' satisfactions on English teacher professionalism in teaching English as foreign language at SMP Negeri 8 Singaraja, it can be conclude that:

The forms of students' satisfaction in this study are categorized into five, namely reliability, responsiveness, empathy, assurance and tangibility. The most prominent form of students' satisfaction is tangibility where the teacher always looks neat and polite whenever 
the teacher is in school's environment which makes students feel comfortable following the learning process.

Students' satisfaction in assurance dimension is also prominent where the teacher can always answer students' question clearly which eases or facilitates students to understand the learning material.

The form of students' satisfaction with the lowest score is in empathy dimension. This low score in empathy dimension is caused by the teacher's behaviour where the teacher puts less attention to the students during the learning process. It's caused because students are unruly during the learning process. Therefore the teacher tends to let the students by themselves in the learning process.

\section{SUGGESTION}

Based on the result of this study, it is suggested for the English teachers and for the other researcher:

1. For the English teacher

a. First, the teachers are suggested to always motivate the students in learning English as Foreign Language in order to the students interested to learning English

b. Second, the teachers also need to prepare the activities that would be given to the students very well, it can improve students' motivation and engagement in the learning process.

c. And for the last, the teacher should be more creative to make the learning English not bored, for example the teacher teach the students using games or song. It is make the students fun at all and happy to study English.

2. For the other researcher

a. It is suggested to other researchers to use this researchas a reference to conduct similar research. Hopefully this research could be useful reference to support similar research that will be conducted.

\section{REFERENCES}

Arikunto, S. (2010). Prosedur penelitian suatu pendekatan praktik. Jakarta: Rineka.

Barnes, C. (2017). An Analysis of Student Perceptions of the Quality and Course Satisfaction of Online Courses, 17(2001), 92-98.

Carter, P. (2014). a Case Study of Student Satisfaction. Proceedings of CLaSIC 2014, Vol.14, 72-77.

Creswell. (2009). Research Design (third edit). SAGE. Retrieved from www.sagepublication.com

Eggen P, Kauchak D (2001). Educational psychology: Windows on classrooms. New Jersey Prentice Hall, Inc.

Guolla, M. (1999). Assessing the teaching quality to student satisfaction relationship: applied customer satisfaction research in the classroom. Journal of Marketing Theory \& Practice vol. 7, 87-96.

Hair J.F. et.al (1995), "Multivariate Data Analysis with Reading”, Fourth Edition, Prentice Hall. New Jersey

Islamiyah, V. N. (2017). Analisis Kepuasan Siswa atas Pembelajaran oleh Guru-guru Bersertifikasi. Universitas Muhammadiyah Surakarta.

Jayanthi, N. S. \& Kumar, R. V. (2016). Use of ICT in English language teaching and learning. 
Journal of English language and literature, 3(2), 34-38.

Kemendikbud. (2017). Pengembangan Keprofesian Guru untuk Peningkatan Profesionalitas. In Jendela Pendidikan dan Kebudayaan. Retrieved from http://repositori.perpustakaan.kemdikbud.go.id/4804/1/EDISI 17 2017.pdf

Khan, A., \& Khan, S. (2016). Impact of Teacher Personality on the Academics of the Students Correspondence: Alamgir Khan, Lecturer, Department of Sports Science \& Physical Education, Gomal University, Khyber Pakhtunkhwa, PAKISTAN, Tel :, (August).

Khan, S. (2017). Teaching Professionalism and Students Academic Achievements. Journal of Physical Education Reseach, Vol.7,No.7, 48.

Kumbakonam, U. R. (2017). Role of a Teacher in English Language Teaching ( Elt ). International Journal of Education, Vol.7(1, Feb 2017, 1-4), 03.

Miles, M., Huberman, A., \& Saldaña, J. (2014). Designing matrix and network displays. Qualitative Data Analysis A Methods Sourcebook, 107-119. https://doi.org/10.1136/ebnurs.2011.100352

Muslich, M. (2012). Sertifikasi Bagi Guru dalam Jabatan: Apa, Mengapa, dan Bagaimana?. Jakarta: Bumi Aksara.

Parasuraman, A, Valerie A. Zeithaml, Leonard L. Berry. (1998) SERVQUAL: A Multiple Item Scale for Measuring Consumer Perception of Service Quality. Journal of Retailing Vol. 64 No. 1, p 12-37.

Presiden Republik Indonesia. (2005). Undang-undang Republik Indonesia Nomor 14 Tahun 2005 tentang Guru dan Dosen. Produk Hukum, 54.

Race, P. (2010). Increasing Students ' satisfaction. Centre for Educational Development, Queen's University Belfast, (11), 1-6. Retrieved from https://www.qub.ac.uk/directorates/AcademicStudentAffairs/CentreforEducationalDevelo pment/FilestoreDONOTDELETE/Filetoupload,218674,en.pdf

Sopiatin, Popi. (2010). Managemen Belajar Berbasis Kepuasan Siswa. Cilegon: Ghalia Indonesia.

Suarman, S. (2015). Teaching Quality and Students Satisfaction: The Intermediatory Role of Relationship between Lecturers and Students of the Higher Learning Institutes.

Mediterranean Journal of Social Sciences, 6(2), 626-632. https://doi.org/10.5901/mjss.2015.v6n2p626

Uka, A. (2014). Student Satisfaction As an Indicator of Quality in Higher Education. Journal of Educational and Instructional Studies, 4(3), 7-10.

Ulug, M., Ozden, M. S., \& Eryilmaz, A. (2011). The effects of teachers' attitudes on students' personality and performance. Procedia - Social and Behavioral Sciences, 30, 738-742. https://doi.org/10.1016/j.sbspro.2011.10.144 